\title{
Ketahanan Bakteri Asam Laktat Asal Saluran Pencernaan Broiler Terhadap pH dan Garam Empedu
}

\author{
Resilience of Lactic Acid Bacteria from Broiler Gastrointestinum on $\mathrm{pH}$ and Bile Salt \\ Dian Setyawati Mansur*, Muhammad Nur Hidayat, Irmawaty \\ Jurusan Ilmu Peternakan Fakultas Sains dan Teknologi \\ Universitas Islam Negeri Alauddin, Makassar \\ *Korespondensi Email: diansetyawatim@gmail.com
}

\begin{abstract}
ABSTRAK
Penelitian ini bertujuan untuk mengetahui ketahanan bakteri asam laktat terhadap $\mathrm{pH}$ dan garam empedu. Metode penelitian dengan menggunakan media MRSA (Man Ragosa Sharpe Agar) dan MRSB (Man Ragosa Sharpe Broth) untuk menumbuhkan bakteri, yaitu dengan melakukan penginkubasian pada suhu $37{ }^{\circ} \mathrm{C}$ terhadap tiap-tiap perlakukan yang di berikan. Untuk perhitungan jumlah koloninya, dilakukan dengan menggunakan koloni kounter. Hasil dari penelitian ini menunjukkan bahwa pertumbuhan isolat bakteri terhadap ketahanan $\mathrm{pH}$ mampu tumbuh pada medium yang telah di inkubasikan selama 48 jam. Pada pH 2,5 dengan jumlah bakteri sebanyak 4,77 unit log (CFU/ml), pada $\mathrm{pH} 3$ dengan jumlah bakteri 6,98 unit $\log (\mathrm{CFU} / \mathrm{ml}), \mathrm{pH} 5$ dengan jumlah bakteri 8,97 unit $\log (\mathrm{CFU} / \mathrm{ml})$ dan $\mathrm{pH} 7$ dengan jumlah bakteri 7,90 unit log (CFU/ml). Sedangkan pada garam empedu isolat bakteri asam laktat juga mampu tumbuh pada medium yang telah diinkubasikan selama 48 jam. Pada garam empedu $1 \%$ jumlah bakterinya sebanyak 7,84 unit $\log (\mathrm{CFU} / \mathrm{ml})$ konsentrsi garam empedu 5\% jumlah bakterinya 6,32 unit $\log (\mathrm{CFU} / \mathrm{ml})$ dan tanpa garam empedu (kontrol) jumlah bakterinya sebanyak 9,3 unit log $(\mathrm{CFU} / \mathrm{ml})$
\end{abstract}

Kata kunci : Bakteri Asam Laktat, pH, Garam Empedu, MRSA dan MRSB.

\begin{abstract}
This study aims to determine the resistance of lactic acid bacteria to $\mathrm{pH}$ and bile salts. Research method using MRSA and MRSB media to grow bacteria, namely by incubating at $37^{\circ} \mathrm{C}$ for each treatment given. For the calculation of the number of colonies, it is done using a colony counter. The results of this study indicate that the growth of bacterial isolates against $\mathrm{pH}$ resistance can grow on incubated medium for 48 hours. At $\mathrm{pH} 2.5$ with the number of bacteria was 4.77 units $\log$ $(\mathrm{CFU} / \mathrm{ml})$, at $\mathrm{pH} 3$ with the number of bacteria 6.98 units $\log (\mathrm{CFU} / \mathrm{ml}), \mathrm{pH} 5$ with the number of bacteria 8.97 units $\log (\mathrm{CFU} / \mathrm{ml})$ and $\mathrm{pH} 7$ with bacterial counts of $7.90 \mathrm{log}$ units $(\mathrm{CFU} / \mathrm{ml})$. While the bile salts isolate lactic acid bacteria are also able to grow on medium that has been incubated for 48 hours. In $1 \%$ bile salts the number of bacteria is 7.84 units $\log (\mathrm{CFU} / \mathrm{ml})$, the concentration of bile salt is $5 \%$ the number of bacteria is 6.32 units $\log (\mathrm{CFU} / \mathrm{ml})$ and in the treatment without bile salt (control) the number of bacteria is 9, $3 \log$ units $(\mathrm{CFU} / \mathrm{ml})$.
\end{abstract}

Keywords: Lactic Acid Bacteria, pH, Bile Salt, MRSA and MRSB. 


\section{PENDAHULUAN}

Kesadaran masyarakat akan pentingnya kesehatan saat ini semakin meningkat, sehingga menimbulkan implikasi yang luas dalam memilih bahan makanan untuk kelangsungan hidup. Hal tersebut mendorong berkembangnya riset-riset mengenai makanan dan minuman yang mempunyai efek menyehatkan, termasuk pangan fungsional yang berasal dari ternak. Bioproduk atau makanan yang mengandung probiotik tergolong kedalam pangan fungsional karena selain mengenyangkan, berpotensi pula meningkatkan fungsi fisiologis usus dengan memodifikasi mikroflora usus. Makanan yang mengandung probiotik selain mempunyai nilai nutrisi yang baik, dianggap pula memberi manfaat kesehatan dan terapeutik serta bisa dijadikan sebagai pengganti antibiotik untuk menekan pertumbuhan bakteri pathogen.

Bakteri asam laktat merupakan jenis bakteri yang mampu menghasilkan asam laktat, hydrogen peroksida, antimikroba dan hasil metabolisme lain yang memberikan pengaruh positif bagi tubuh. Bakteri asam laktat diisolasi untuk menghasilkan antimikroba yang dapat digunakan sebagai probiotik. Bakteri ini berbentuk batang atau kokus yang mempunyai karatkeristik gram positif, tidak membentuk spora, tidak motil, tidak membentuk pigmen, katalase dan asam laktat sebagai senyawa utama hasil fermentasi karbohidrat.Secara umum bakteri ini menghendaki senyawa nutrisi yang kompak dan pertumbuhannya distimulasi oleh suasana anaerob dan mikroaerofil (Kuswanto dan Sudarmadji, 1989).

Probiotik merupakan suplemen pangan yang berasal dari mikroba hidup yang menguntungkan kesehatan inangnya dengan cara memperbaiki komposisi mikrobiota usus. Bakteri asam laktat, khususnya yang bersifat sebagai prebiotik, banyak digunakan sebagai suplemen pangan dengan berbagai manfaat bagi kesehatan. Bakteri ini, khususnya dari golongan Lactobacillus dan Bifidobacteria memiliki banyak efek positif seperti aktivitas antimikroba, aktivitas antikolesterol, efek stimulasi system imun, meningkatkan penyerapan laktosa oleh tubuh, mencegah diare serta aktivitas antimutagenik sehingga dapat mencegah penyakit kanker khususnya kanker usus (Susanti dkk., 2007).

Bakteri probiotik merupakan mikroorganisme non patogen, yang jika di konsumsi memberikan pengaruh positif terhadap fisiologi dan kesehatan inangnya, Senyawa-senyawa racun yang dihasilkan dari metabolisme protein dan lemak, serta hasil pemecahan enzim tertentu menjadi semakin berkurang bila bakteri probiotik mulai menjalankan peranannya dalam meningkatkan kesehatan.Probiotik merupakan salah satu alternatif pakan tambahan 
Dian Setiawaty Mansyur dkk., 29

pada ternak yang sehat dan aman bagi lingkungan. Selain itu mikroba prebiotik mampu memproduksi substansi berguna, dapat menurunkan populasi mikroba patogen, meningkatkan kesehatan dan daya imunitas ternak (Sjofjan, 2003).

Ada beberapa karateristik yang harus dipertimbangkan untuk menentukan apakah suatu mikroba berpotensi untuk menjadi kultur probiotik. Diantaranya adalah ketahanan terhadap asam dan garam empedu, sebab untuk dapat bertahan dan tumbuh didalam saluran pencernaan, kultur probiotik harus melewati beberapa rintangan seperti keasaman lambung yang tinggi dan sekresi garam empedu pada usus yang dapat berpengaruh buruk pada kultur mikroba. Disamping itu bakteri tersebut juga harus mampu bersaing dengan bakteri enterik patogen dalam saluran pencernaan (Purwohadisantoso, 2008).

\section{MATERI DAN METODE}

Bahan yang digunakan dalam penelitian ini adalah alcohol $70 \%$, aluminium foil, aquades, $\mathrm{BPW}$, garam empedu, $\mathrm{HCl} 100 \%$, isolate bakteri asam laktat, kapas, karet, medium selektif MRSA (Man Ragosa Sharpe Agar), medium selektif MRSB (Man RagosaSharpe Broth), kapas, plastik dan tissu.

\section{Prosedur kerja}

Prosedur kerja yang akan dilakukan pada penelitian ini adalah sebagai berikut :

\section{Tahap Persiapan}

\subsection{Sterilisasi Alat dan Medium}

a. Alat-alat gelas berupa tabung reaksi dan cawan petri disterilkan dengan sterilisasi panas basah pada autoklaf. Sterilisasi ini dilakukan selama 15 menit dalam temperatur $121^{\circ} \mathrm{C}$ dan tekanan $2 \mathrm{~atm}$.

b. Jarum ose disterilkan dengan sterilisasi panas kering dalam nyala api bunsen sampai merah membara.

c. Medium dan alat non-gelas yang digunakan terlebih dahulu disterilkan dengan sterilisasi panas basah yaitu dengan menggunakan autoklaf. Sterilisasi ini dilakukan selama 15 menit dalam temperatur $121^{\circ} \mathrm{C}$ dan tekanan $2 \mathrm{~atm}$.

1.2 Pembuatan Medium MRSA dan MRSB

a. MRSA

Sebanyak 34,1 gram medium MRSA dilarutkan ke dalam $500 \mathrm{ml}$ aquades. Kemudian dipanaskan sambil diaduk sampai homogen. Lalu mulut masing- 
masing Erlenmeyer ditutup dengan menggunakan aluminium foil lalu disterilkan dalam autoklaf dengan suhu $121^{\circ} \mathrm{C}$ selama 15 menit.

b. MRSB

Sebanyak 32,6 gram medium MRSB dilarutkan ke dalam $500 \mathrm{ml}$ akuades. Kemudian dipanaskan sambil diaduk sampai homogen. Lalu mulut masingmasing Erlenmeyer ditutup dengan menggunakan aluminium foil lalu disterilkan dalam autoklaf dengan suhu $121^{\circ} \mathrm{C}$ selama 15 menit. Selanjutnya larutan dibagi ke dalam 55 buah tabung reaksi masing-masing sebanyak $9 \mathrm{ml}$.

1.3 Pembuatan BPW

Sebanyak 12,5 gram medium BPW dilarutkan ke dalam $650 \mathrm{ml}$ aquades kemudian dipanaskan sambil diaduk sampai homogeny. Lalu mulut masingmasing Erlenmeyer ditutup menggunakan aluminium foil lalu disterilkan dalam autoklaf dengan suhu $121^{\circ} \mathrm{C}$ selama 15 menit.

\section{Tahap Pelaksanaan}

\subsection{Pengujian Ketahanan Terhadap $\mathrm{pH}$}

Sebelum dilakukan pengujian, kultur sebelumnya diremajakan dengan cara mengambil $1 \mathrm{ml}$ kemudian di tanam pada medium MRSB lalu diinkubasikan selama 24 jam. Selanjutnya mengambil 4 tabung reaksi yang berisi $9 \mathrm{ml} \mathrm{MRSB}$, yang telah ditambahkan $\mathrm{HCl}$ 100\% untuk mendapatkan $\mathrm{pH}$ yang diinginkan. Lalu mengambil masing-masing $1 \mathrm{ml}$ isolat bakteri asam laktat kemudian di masukkan ke dalam 4 tabung yang berisi $9 \mathrm{ml}$ MRSB dan selanjutnya di inkubasi pada suhu $37^{\circ} \mathrm{C}$ selama 48 jam.

\subsection{Pengujian Ketahanan Terhadap Garam Empedu}

Sebelum dilakukan pengujian, kultur sebelumnya diremajakan dengan cara mengambil $1 \mathrm{~mL}$ kemudian di tanam pada medium MRSB lalu diinkubasikan selama 24 jam. Selanjutnya mengambil 4 tabung reaksi yang berisi $9 \mathrm{~mL}$ MRSB yang telah ditambahkan garam empedu 1\% dan 5\%. Lalu mengambil masingmasing $1 \mathrm{~mL}$ isolat bakteri asam laktat kemudian di masukkan ke dalam 4 tabung yang berisi $9 \mathrm{~mL}$ MRSB kemudian di inkubasi pada suhu $37^{\circ} \mathrm{C}$ selama 48 jam.

1.3 Seleksi Media Agar

a. Memipet sebanyak $1 \mathrm{ml}$ sampel

b. Memasukkan ke dalam cawan petri yang berisi $20 \mathrm{ml}$ MRSA 
c. Menghomogenkan dengan kecepatan sedang selama 1-2 menit

d. Menginkubasikan pada temperature $37^{\circ} \mathrm{C}$ selama 48 jam

\subsection{Pewarnaan Gram}

a. Mengambil isolat pada medium MRSA menggunakan ose kemudian diletakkan pada objek glass lalu difiksasi.

b. Memberi kristal violet sebanyak 2 tetes kemudian didiamkan selama 1 menit, lalu dibilas menggunakan akuades.

c. Memberi lugol sebanyak 2 tetes kemudian didiamkan selama 1 menit, lalu dibilas menggunakan akuades.

d. Memberi alkohol 95\% sebanyak 2 tetes kemudian didiamkan selama 1 menit, lalu dibilas menggunakan akuades.

e. Memberi safranin sebanyak 2 tetes kemudian didiamkan selama 1 menit, lalu dibilas menggunakan akuades.

f. Memberi imersion oil, lalu diamatai di bawah mikroskop dengan perbesaran $100 \mathrm{X}$

1.5 Perhitungan Jumlah Bakteri yang Tumbuh

Ketahanan isolate bakteri asam laktat terhadap $\mathrm{pH}$ dan garam empedu dihitung berdasarkan selisih unit log jumlah koloni yang tumbuh setelah 48 jam pada $\mathrm{pH}$ 2.5, $\mathrm{pH} 3, \mathrm{pH} 5$, pH 7 serta pada garam empedu 1\% dan $5 \%$ terhadap unit log jumlah koloni.

Rumus perhitungan jumlah mikroba:

Populasi BAL $(\mathrm{CFU} / \mathrm{mL})=$ Jumlah koloni X Pengenceran

\section{Analisis Data}

Analisis data yang digunakan dalam penelitian ini adalah analisis deskriptif antara lain dengan melihat hasil uji probiotik (suhu) isolat bakteri asam laktat asal saluran pencernaan broiler. Isolasi bakteri dimana seluruh data diperoleh dari seluruh pengamatan (positif atau negatif) yang ditunjukkan pada beberapa indikator uji yang telah dilakukan yakni, pengumpulan data dan pengamatan secara langsung dan dengan cara dokumentasi untuk dijadikan hasil bukti penelitian. 


\section{HASIL DAN PEMBAHASAN}

\section{Pengamatan Morfologi Pewarnaan Gram Menggunakan Mikroskop}

Berdasarkan hasil pewarnaan Gram isolat bakteri yang diuji dalam penelitian ini memiliki bentuk batang dan bersifat Gram positif. Hal ini ditandai dengan terbentuknya warna ungu pada sel bakteri yang menandakan termasuk Gram positif, sedangkan Gram negatif ditandai dengan terbentuknya warna merah pada sel bakteri. Bakteri Gram positif dapat mempertahankan warna ungu disebabkan ketika ditetesi alkohol 95\% dinding sel mengalami dehidrasi sehingga menyebabkan ukuran pori-pori sel menjadi kecil dan daya permetabilitasnya berkurang sehingga zat pewarna kristal violet tidak dapat keluar dari sel dan sel akan tetap berwarna ungu. Pemberian pewarna tandingan berupa safranin yang berwarna merah tidak akan berpengaruh karena tidak masuk ke dalam dinding sel. Sebaliknya bakteri Gram negatif tidak mampu mempertahankan warna kristal violet karena pada saat dibilas dengan alkohol 95\%, lipid dari dinding sel terekstrasi, pori-pori sel mengembang sehingga zat pewarna kristal violet keluar dari sel dan membuat sel jadi tidak berwarna.

Prinsip pewarnaan Gram adalah kemampuan dinding sel mengikat zat warna dasar (Kristal violet) setelah pencucian dengan alkohol 95\%. Keadaan ini berhubungan dengan komposisi senyawa penyusun dinding sel. Pada bakteri Gram positif mengandung peptidoglikan lebih banyak dan lemak lebih sedikit dibandingkan bakteri Gram negatif (Syulasmi dkk., 2005).

Berdasarkan pengujian fermentasi gula yang dilakukan sebelumnya isolat yang digunakan adalah jenis bakteri Lactobacillus sp. Menurut Ray (2001), menyatakan bahwa Lactobacillus sp. memiliki ciri-ciri yaitu selnya berbentuk batang dengan ukuran dan bentuk yang sangat seragam, beberapa bias sangat panjang dan beberapa lainnya bersifat batang bulat.

\section{Pengujian Isolat Bakteri Asam Laktat Terhadap Keasaman (pH)}

Berdasarkan hasil penelitian dengan melakukan uji isolat bakteri terhadap kadar keasaman. Hasil pengujian tersebut dapat di lihat bahwa pada 24-48 jam isolat bakteri asam laktat menunjukkan pertumbuhan pada semua media yang di ujikan, yaitu $\mathrm{pH} 2.5, \mathrm{pH} 3$ dan pH 5. 


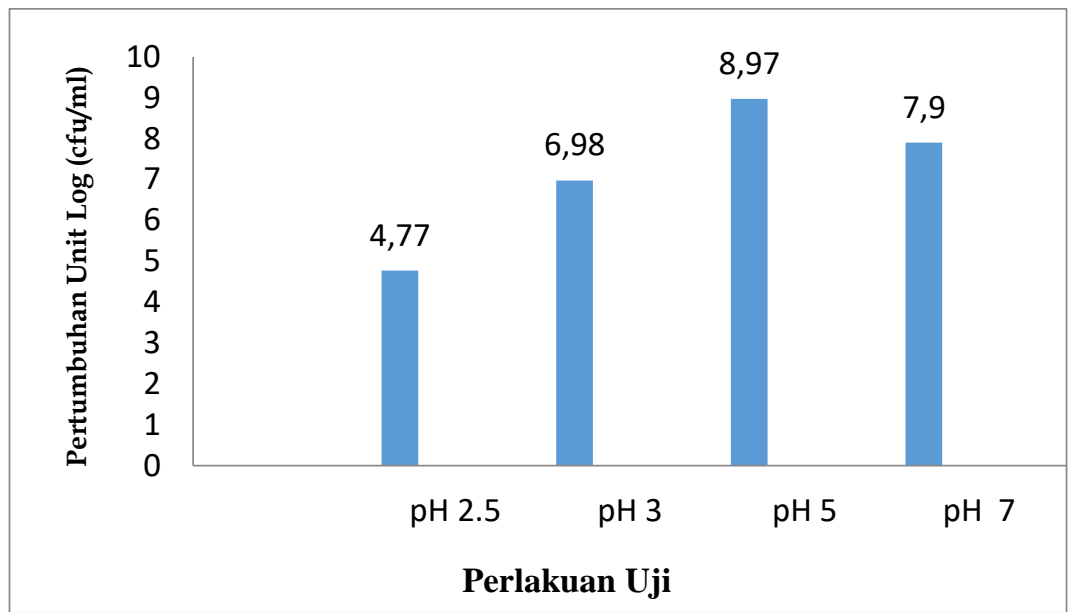

Gambar 2. Grafik Pertumbuhan Koloni Bakteri Asam Laktat terhadap Kadar Keasaman (pH)

Berdasarkan Uji probiotik terhadap ketahanan asam $(\mathrm{pH})$ dilakukan dengan menggunakan medium MRSB yang ditambahkan $\mathrm{HCl} 100 \mathrm{~N}$ untuk mendapatkan pH 2.5, pH 3 dan pH 5. Pengujian dilakukan dengan menumbuhkan isolat bakteri asam laktat tersebut pada media yang telah di buat selama 48 jam di dalam inkubator bersuhu $37{ }^{\circ} \mathrm{C}$. Hasil dari pengujian tersebut dapat di lihat bahwa pada 48 jam isolat bakteri asam laktat menunjukkan pertumbuhan pada $\mathrm{pH} 2.5, \mathrm{pH} 3$ dan $\mathrm{pH} 5$ yang dapat di lihat dari warna media yang berubah menjadi keruh dan terdapat endapan.

Berdasarkan perhitungan unit Log terhadap ketahanan asam $(\mathrm{pH})$ dilakukan dengan menggunakan medium MRSA dengan metode yang digunakan, yaitu cawan tuang dengan menambahkan masing-masing $1 \mathrm{ml}$ isolat bakteri asam laktat bedasarkan $\mathrm{pH}$ perlakuan yaitu pH 2.5, pH 3, pH 5 dan pH 7 sebagai kontrol lalu menambahan 20 ml MRSA kedalam cawan lalu di homogenkan. Pengujian dilakukan dengan menumbuhkan isolat bakteri asam laktat tersebut pada media yang telah di buat selama 48 jam di dalam inkubator bersuhu $37{ }^{\circ} \mathrm{C}$. Hasil dari pengujian tersebut dapat di lihat bahwa pada 48 jam isolat bakteri asam laktat menunjukkan pertumbuhan pada masing-masing cawan. Pada $\mathrm{pH}$ 2,5 jumlah bakteri sebanyak 4,77 unit log (CFU/ml), pH 3 jumlah bakteri sebanyak 6.98 unit log (CFU/ml), pH 5 jumlah bakteri sebanyak 8.97 unit $\log (\mathrm{CFU} / \mathrm{ml}), \mathrm{pH} 7$ jumlah bakteri sebanyak 7.90 unit $\log (\mathrm{CFU} / \mathrm{ml})$.

Pengaruh $\mathrm{pH}$ terhadap pertumbuhan bakteri ini dapat di lihat dari adanya pertumbuhan pada tiap-tiap perlakukan $\mathrm{pH}$, yaitu dilihat dari jumlah selisih unit log. Secara umum, isolate bakteri asam laktat pada $\mathrm{pH} 2.5$ pertumbuhan jumlah koloni yang paling 
sedikit yaitu 4.77 unit $\log (\mathrm{CFU} / \mathrm{ml})$, pada $\mathrm{pH} 3$ mengalami peningkatan jumlah koloni yaitu sekitar 6.98 unit $\log (\mathrm{CFU} / \mathrm{ml})$, pertumbuhan koloni paling optimum terdapat pada $\mathrm{pH} 5$ yaitu sebanyak 8.97 unit $\log (\mathrm{CFU} / \mathrm{ml})$. sedangkan pada $\mathrm{pH} 7$ terjadi penurunan, yaitu sekitar 7.90 unit $\log$ (CFU/ml). Menurut Jacobsen et al., (1999), semua bakteri yang berhasil bertahan pada kondisi $\mathrm{pH}$ dinyatakan bersifat tahan atau resisten terhadap asam.

Pertumbuhan paling optimum terlihat pada $\mathrm{pH} 5$ yang memiliki ketahanan terhadap $\mathrm{pH}$ asam yang lebih baik di banding dengan isolat pada $\mathrm{pH}$ lainnya yang di tunjukkan dengan pertumbuhan yang paling banyak yaitu 8.97 unit $\log (\mathrm{CFU} / \mathrm{ml})$. namun semua isolate mampu hidup pada $\mathrm{pH}$ 2.5, pH 3 pH 5 dan $\mathrm{pH} 7$ sehingga masih terdapat sel yang lolos hidup pada saat melewati lambung dan usus halus bila di berikan bersama-sama dengan pakan, karena $\mathrm{pH}$ saluran pencernaan lambung berkisar 2,5 dan $\mathrm{pH}$ usus halus berkisar 3-5.

Berdasarkan hasil pengujian isolat bakteri probiotik mampu tumbuh pada $\mathrm{pH}$ 2,5 dan usus halus 3-5. Hal ini membuktikan isolat BAL tersebut mampu untuk melewati asam lambung sehingga dapat dimanfaatkan sebagai bakteri probiotik. $\mathrm{pH}$ medium biakan mempengaruhi kecepatan pertumbuhan, untuk pertumbuhan bakteri juga terdapat rentang $\mathrm{pH}$ dan $\mathrm{pH}$ optimal. Meskipun medium pada awalnya dikondisikan dengan $\mathrm{pH}$ yang dibutuhkan untuk pertumbuhan, tetapi secara bertahap pertumbuhan akan dibatasi oleh produk metabolit yang dihasilkan oleh mikroorganisme tersebut (Djide dan Wahyudi, 2008).

\section{Pengujian Isolat Bakteri Asam Laktat Terhadap Garam Empedu}

Berdasarkan Uji probiotik terhadap garam empedu dilakukan dengan menggunakan medium MRSB yang ditambahkan garam empedu 1\% dan 5\%. Pengujian dilakukan dengan menumbuhkan isolat bakteri asam laktat tersebut pada media yang telah di buat selama 48 jam di dalam inkubator bersuhu $37^{\circ} \mathrm{C}$. Hasil dari pengujian tersebut dapat dilihat bahwa pada 48 jam, isolat bakteri asam laktat menunjukkan pertumbuhan pada garam empedu 1\% dan $5 \%$ yang ditandai warna media yang berubah menjadi keruh dan terdapat endapan.

Berdasarkan perhitungan unit Log terhadap garam empedu dilakukan dengan menggunakan medium MRSA dengan metode cawan tuang, menunjukkan bahwa pada inkubasi 48 jam, isolat bakteri asam laktat menunjukkan pertumbuhan pada masing-masing cawan. Pada garam empedu 1\% jumlah bakterinya sebanyak 7.84 unit log (cfu/ml), garam 
empedu 5\% jumlah bakterinya sebanyak 6.32 unit $\log (\mathrm{cfu} / \mathrm{ml})$, sedangkan pada perlakuan tanpa garam empedu (kontrol) jumlah bakterinya sebanyak 9.3 unit log (cfu/ml).

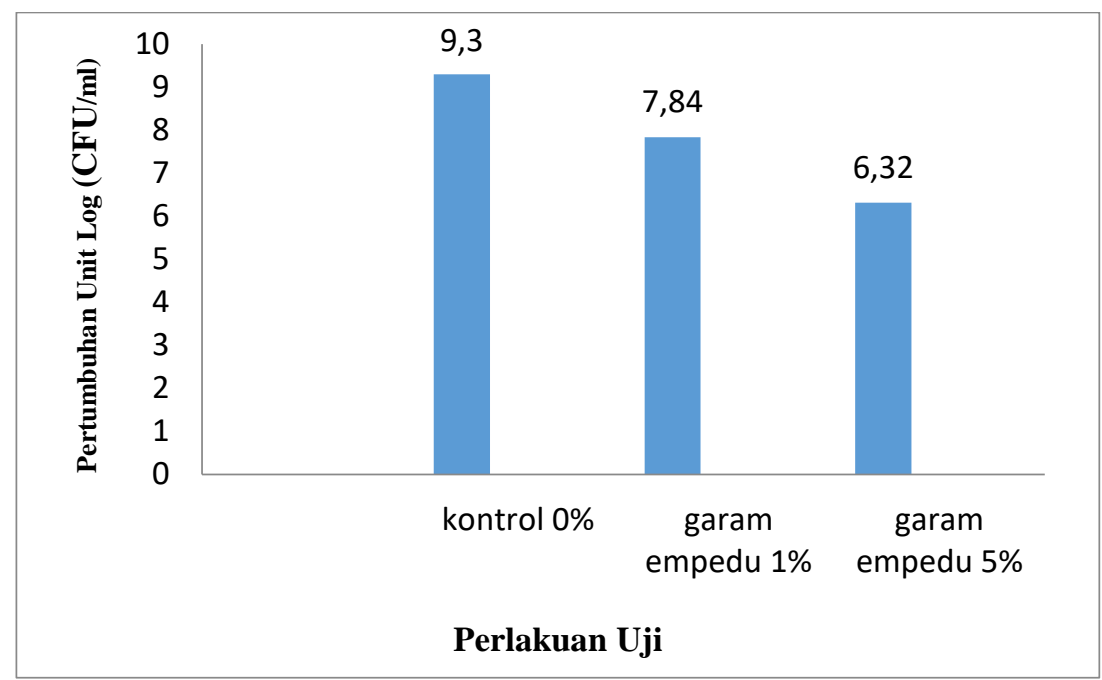

Gambar 4. Grafik Pertumbuhan Koloni Bakteri Asam Laktat terhadap Kadar Garam Emepdu

Hasil pengujian ketahanan isolat terhadap konsetrasi garam empedu $1 \%$ memperlihatkan pertumbuhan bakterinya lebih banyak di bandingkan dengan konsentrasi $5 \%$. Banyaknya pertumbuhan pada konsentrasi $1 \%$ ini di sebabkan karena konsetrasi garam empedunya tidak terlalu tinggi. Sedangkan pada konsentrsi $5 \%$ mengalami penurunan karena garam empedu yang di berikan terlalu banyak. Semakin tinggi konsentrasi garam empedu, maka jumlah sel mikroba yang mati juga akan meningkat. Hal ini disebabkan peningkatan aktivitas enzim intraseluler dari bakteri terhadap garam empedu, sehingga meningkatkan permeabilitas membrane sel (Wijayanto, 2009). Hal ini sesuai dengan pendapat Menurut Zavaglia et al., (1998), yang menyatakan konsentrasi gram empedu 3\% merupakan konsentrasi yang cukup tinggi untuk menyeleksi galur yang resisten terhadap garam empedu.

Mikroba yang berhasil hidup setelah ditumbuhkan dalam MRSA yang ditambah 1\% dan 5\% garam empedu, dinyatakan bersifat tahan terhadap garam empedu. Hal ini mengindikasikan bahwa isolat bakteri asam laktat dari saluran pencernaan broiler ini berpotensi untuk dikembangkan sebagai probiotik. Menurut Hidayat et al., (2018), bahwa kemampuan bakteri untuk dapat bertahan pada kondisi garam empedu yang diuji secara in 
vitro dapat dikatakan memiliki kemampuan untuk melewati bagian saluran pencernaan, khususnya pada bagian duodenum pada unggas.

Mekanisme penghambatan garam empedu terhadap pertumbuhan bakteri disebabkan karena garam empedu memiliki struktuk amphipatik sehingga mampu melarutkan atau memecah semua substansi sel yang mengandung lipid. Dinding sel bakteri dan membran sel bakteri mengandung lipid sehingga masuknya garam empedu ke dalam dinding sel dan membran sel akan menyebabkan dinding sel dan membran sel menjadi rusak dan kehilangan fungsinya sebagai pelindung bakteri dan filter. Apabila bakteri mengalami kerusakan atau kehilangan fungsi pada dinding selnya, maka akan mengakibatkan bakteri cenderung tidak mampu bertahan terhadap tekanan osmotik sehingga menyebabkan terjadinya lisis atau pengeluaran isi sel yang berakibat kematian sel (Hill, 1995; Mourad and Eddine, 2006).

\section{KESIMPULAN DAN SARAN}

Berdasarkan hasil penelitian diperoleh bahwa isolat bakteri asam laktat asal saluran pencernaan broiler itu dapat di manfaatkan sebagai probiotik. Bakteri tersebut mampu tumbuh pada kondisi $\mathrm{pH}$ dan konsentrasi garam empedu yang berbeda. Bedasarkan hal tersebut, maka bakteri asam laktat yang di peroleh dari saluran pencernaan broiler yang paling baik manfaatkan sebagai kandidat probiotik yaitu pada $\mathrm{pH} 5$, karena pada $\mathrm{pH}$ ini bakteri paling optimum tumbuh yaitu sebanyak 8.97 unit log (CFU/ml). Sedangkan pada garam empedu itu paling optimum di konsentrasi 1\% yaitu sebanyak 7.84 unit log $(\mathrm{CFU} / \mathrm{ml})$.

\section{DAFTAR PUSTAKA}

Djide, M. N., dan Wahyudin E. 2008. Isolasi bakteri asam laktat dari air susu ibu, dan potensinya dalam menurunkan kadar kolesterol secara in vitro. Majalah Farmasi dan Farmakologi.

Hidayat, M.N., Malaka, R., Agustina, L., and Pakiding, W. 2018. International Journal of Scientific \& Engineering Research 9(2), 1787-1794.

Hill, M. J. 2006. Role of Gut Bacteria in Human Toxicology and Pharmacology. Taylor, New York. Jacobsen, C. N., Nielsen, V.R., Hayford, A.E., Moller, P.L., Michaelsen, K.F., Erregard, A.P., B. Sandstrom, B., Tvede, M., and Jakobsen, M. 1999. Screening of probiotic activities of forty seven strains of Lactobacillus spp. by in vitro techniques and evaluation of the colonization ability of five selected strains in human. Journal Applied Environmental Microbiology, 65(11), 4949-4956.

Kuswanto, R. K., dan Sudarmadji, S. 1989. Mikrobiologi Pangan. Universitas Gajah Mada, Yogyakarta. 
Dian Setiawaty Mansyur dkk., 37 JiiP Volume 5 Nomor 1: 27-37, Juni 2019

Purwohadisantoso K. 2008. Isolasi bakteri asam laktat dari sayur kubis yang memiliki kemampuan penghambatan terhadap bakteri patogen. Skripsi. Fakultas Teknologi Pertanian. Universitas Brawijaya Malang.

Ray B. 2001. Fundamental Food Microbiology. Ed-2. CRC Press, New York.

Sjofjan, O. 2003. Kajian probiotik AB (Aspergillu ssp. dan Bacillus ssp.) sebagai imbuhan ransum dan implikasi efeknya terhadap mikroflora usus serta penampilan produksi ayam petelur. Disertasi.Program Pascasarjana. Universitas Padjadjaran,Bandung.

Susanti, I., Retno, W K., dan Fatim I. 2007. Uji sifat probiotik bakteri asam laktat sebagai kandidat bahan pangan fungsional. Jurnal Teknologi dan Industri Pangan, 13(2).

Syulasmi, A., Hamdiyati, Y., dan Kusnadi. 2005. Petunjuk Praktikum Mikrobiologi. Fakultas Peternakan. Institut Pertanian Bogor, Bogor.

Wijayanto U. 2009. Analisis in vitro toleransi isolat bakteri asam laktat asal daging sapi terhadap $\mathrm{pH}$ lambung, $\mathrm{pH}$ usus dan garam empedu sebagai kandidat probiotik. Skripsi. Fakultas Peternakan. Institut Pertanian Bogor, Bogor.

Zavaglia, A. G., G. Kociubinski., G., and Antoni G. D. 1998. Isolation and characterization of Bifidobacterium strains for probiotic formulation. Journal Food Protection, 61(7), 865-873. 